\title{
1. Digital Games and the Advertising Landscape: An Introduction
}

\section{The Relevance of Understanding the Advertising Potential of Digital Games}

According to the game scholar Ilya Vedrashko, the origin of advergames can be dated to the early 1980 s, and it is even possible to find some precedents in the 196os and '7os (Vedrashko, 2006b). However, the term was not coined until 2000, when the entrepreneur Anthony Giallourakis, owner of the domain www.advergames.com, understood that "the market for interactive casual Internet based gaming would be too appealing to corporations for them to ignore the marketing and branding opportunities associated with casual gaming on the Internet" (Giallourakis, n.d., para. 1) and decided to coin the concept and buy several domains related to it.

The evolution of the game industry and changes in the advertising landscape in recent years are responsible for this increasing interest of marketers in using digital games for advertising purposes. The development of new technologies and the spread of broadband and mobile devices have facilitated the growth of the game industry ${ }^{1}$ and the popularization of digital games, which undoubtedly are related to the increasing interest in the use of digital games as a marketing strategy.

One of the results of the changes in the game industry was what was dubbed by Jesper Juul as the Casual Revolution, "a breakthrough moment in the history of video games" (2010, p. 2). This revolution is a process in which digital games have become more normal and part of people's daily routines for three reasons. Firstly, these new digital games, known as casual games, do not ask players to readjust their schedules as they can be played anytime and anywhere, thanks to their presence on mobile devices. Think, for example,

1 DFC Intelligence, a strategic market research and consulting firm focused on interactive entertainment, forecasted that consumer spending on video games would grow to over $\$ 81$ billion by 2016. The firm has reported that the worldwide video game industry generated $\$ 67$ billion in 2011 (DFC Intelligence, 2011).

De la Hera, Teresa, Digital Gaming and the Advertising Landscape. Amsterdam: Amsterdam University Press, 2019. DOI 10.5117/9789462987159_INTRO 
of an employee playing on her/his way home. Secondly, casual games do not require players to spend hours in order to make progress in a game; for example, a player who is chatting with a friend on Facebook can leave the conversation for a moment, enter Farmville (Zynga, 2009), collect some vegetables, and return to the chat before his friend has noticed the absence. Finally, casual games "fit the social contexts in which people are already spending their time" (2010, p.1). ${ }^{2}$ Games such as Fortnite (Epic Games (2017) and mobile games such as Fingle (Game Oven, 2012) are perfect examples of games that are regular features of social gatherings. Accordingly, a digital game that brings together these three characteristics is appealing not only for players, but also for marketers, who recognize them as an attractive medium for conveying advertising messages without disturbing consumers.

Besides the evolution of the game industry, the changes in the advertising landscape have also facilitated the popularization of advergames as a marketing strategy in recent years. The poor economic conditions and the declining readership of printed media ${ }^{3}$ have motivated marketers to shift their budgets from traditional to interactive media. ${ }^{4}$ Interactive tools are considered less expensive, more measurable, and better than traditional media in provoking a direct response (Forrester, 2009, p. 2). Among the strategies that marketing departments are investing in are search marketing 5 (including paid inclusion and search-engine optimization, SEO), integrated campaigns in social media, display advertising, influencer marketing, and viral marketing. However, banners, pop-ups, and pop-unders, the most popular advertising models on the internet are considered ineffective, because the user often perceives them as a nuisance. They work much better when located on sites with related content (see McCoy, Everard, Galletta, \& Polak, 2004, p. 4). The current trend of advertising to morph into another

2 The Essential Facts About the Computer and Video Game Industry report reveals that in 2011, $65 \%$ of North American gamers played games with other gamers in person - figures show a $64 \%$ increase in 2010 and $62 \%$ in 2009 - and that $45 \%$ of parents play computer and video games with their children at least once a week, a $36 \%$ increase over 2007 (Entertainment Software Association, 2011).

3 "Consumer readership of newspapers and magazines has dropped $17 \%$ and $6 \%$, respectively, since 2004 while offline publishers have struggled to translate their impression-based ad sales model into viable online business" (Forrester, 2009, p. 2).

4 In 2011, advertisers spent $\$ 80.2$ billion on the online market, which is a $17.2 \%$ growth from 2010. The worldwide ad spending total came to $\$ 496.9$ billion in 2011 , up from $\$ 475.7$ billion in 2010, and online advertising market growth is playing a big role in these numbers (Nielsen, 2011). 5 "Search marketing is the application of all tactical elements associated with the search industry and manipulated to form a plan or strategy to achieve online goals" (Colbon, 20o6, p. 3). In 2008, Google earned $\$ 15$ billion from this form of advertising (Karp, 2008). 
form of entertainment seems to offer ways to overcome consumer resistance to advertising messages. ${ }^{6}$ This form of advertising blurs conventional distinctions between advertising and entertainment. It is essentially a fusion of the two into one product, generally funded entirely by a brand or corporation and intended to be distributed as entertainment content, albeit with a highly branded quality.

Given these factors, marketers, aware of the opportunities presented by a diversifying and expanding digital-games-playing population, also started taking advantage of this tendency of advertising to morph into another form of entertainment, which resulted in increasing investment in advergames. ${ }^{7}$ Nowadays, advergames can be found in branded microsites, game portals, social media, and application stores. People play them on mobile phones, desktop computers, laptops, and tablets, and the most successful ones are spread virally worldwide.

A good example of the potential of advergames to become successful advertisements is Hotel 626 (Goodbye, Silverstain, \& Partners, 2008), a scary advergame released to bring two Doritos snacks flavors back from the dead in time for Halloween. This advergame was selected as one of the 25 case studies that illustrate the book The Best Digital Marketing Campaigns in the World (D. Ryan \& Jones, 2011). In the game, which was only available to be played in the dark, between 6 p.m. and 6 a.m., players were trapped in a hotel and they needed to find their way out. More than twelve million visitors played Hotel 626 for an average stay of thirteen minutes per person/ session. Moreover, Doritos' Halloween flavors sold out in stores within three weeks of launch (Ibid., p. 40).

Nonetheless, not all advergames can be used as examples of successful advertising campaigns. One of the main reasons for this uneven performance is the lack of knowledge that marketers and marketing companies have about the potential of digital games as a medium to convey advertising

6 "Empowered consumers today expect a customized, interactive brand experience that goes way beyond a 30 -second television spot or two-dimensional print ad. Forty-two percent of online adults and $55 \%$ of online youth want to engage with their favorite brands through social applications" (Forrester, 2009, p. 2).

7 According to the strategic market research company DFC Intelligence, in 2011 advertisers in North America alone spent over $\$ 1$ billion advertising their products and services through digital games. This includes in-game advertising, around-game advertising, and advergames. By 2014, that figure nearly doubled to over $\$ 2$ billion. Among the different marketing strategies using digital games to advertise products or services, the report reveals a remarkable growth in the advergaming strategy that managed to grab $\$ 344$ from that $\$ 1$ billion in 2011 and which DFC Intelligence predicts will "account for about $78 \%$ of total game advertising revenue" by 2016 (DFC Intelligence, 2011). 
messages. The development of an advergame is a process in which the client and the company responsible for the game design need to communicate to create the most efficient product according to the needs of the advertising campaign. In some cases, the client contact the game studio responsible for the game design directly, and in other cases a marketing company will mediate between the two. However, many marketers and marketing companies, even those specialized in digital marketing, still lack knowledge of game design. Most game designers, in turn, lack knowledge of marketing and persuasive strategies. This situation results in an underutilization of the potential of digital games as an advertising medium. ${ }^{8}$ Moreover, there is still a lack of reliable data on advergames' effectiveness, as will be illustrated in chapter 4 , and thus there is an unwillingness to invest in costly projects.

In summary, although digital games have been used for more than three decades as a medium to convey advertising messages, the lack of knowledge on this subject has led advergame designers to borrow creative strategies from other media, which do not always work due to the interactive nature of digital games. In addition, many advergames concepts are designed by marketing companies who are more worried about conveying an advertising message than about creating games that motivate players to play them and keep playing. It follows that a better understanding of how digital games can be used to convey advertising messages is an important contribution not only to the academic study of this subject, but also to the advergames industry. Furthermore, a deep understanding of the persuasive potential of digital games is of special relevance to properly regulate this marketing strategy and prevent unethical practices.

In this book, I approach the study of advergames from an interdisciplinary perspective in which I use theories from the fields of game studies, media studies, and studies on persuasion undertaken from a humanities perspective. This interdisciplinary approach allows me to broaden the understanding of how persuasiveness can be implemented within digital games by forging new interdisciplinary links within the area of game studies, where the emphasis of this study clearly lies, while also taking up new subjects that are important to this field. Furthermore, I look at contemporary design theories and their relation to games as well as how this relationship may be used in a practical context.

8 It follows that the development of an advergame is a process in which many human actors are involved, namely corporate decision-makers, marketing directors, advergames developers, advertisers, etc. In order to facilitate the reading of this book, henceforth I will use the word "brand" as an abstract term to refer to the different human actors involved in this process. 


\section{Book Structure and Chapter Preview}

\section{Part I: Digital Games as Advertising Medium}

\section{Advergames: A Definition}

In the second chapter of this book, I propose a new definition of the term advergame. In order to propose an accurate definition, I undertake a critical overview of definitions previously proposed by other scholars.

\section{Advergames' History}

The third chapter provides an historical overview of advergames. Advergames' precedents and evolution is an unexplored topic. The only text that I could find on this subject, written by the advertising scholar Ilya Vedrashko in 2006, remains unpublished. This chapter gathers the information collected by Vedrashko and enhances and updates it with new data. The intention of this chapter is to illustrate that, despite the fact that technology has rapidly evolved and has given rise to many different forms of advergames, each one of them with characteristics that can be used to enhance branded experiences, these features are not always exploited and are sometimes incorrectly utilized because of a lack of understanding of the medium.

\section{Advergames' Effectiveness}

Finally, the fourth chapter focuses on advergames' effectiveness. The academic study of advergames has been orientated primarily toward reception analysis. However, it is usual to find articles in which the effectiveness of advergames is assessed by applying methodological frameworks borrowed from other fields and not designed specifically to be applied to this object of study (e.g. Pinto Neto, 2007). In this chapter, I identify the factors that determine advergames' effectiveness.

\section{Part II: Persuading Players through Digital Games}

5. The Procedural School: A Critical Analysis

In the fifth chapter, I undertake a critical review of the literature of previous research that has contributed to understanding how games can be used to convey advertising messages. This literature review is organized around game scholar Ian Bogost's (2007) theory on procedural rhetoric due to the high relevance of the procedural school to the study of digital games' persuasiveness. This literature review is divided into two main sections: in the first section I focus the analysis on Bogost's definition and study of 
persuasive games, and in the second section I analyze Bogost's application of his theory about persuasive games to the domain of advergames. The objectives of this literature review are to pinpoint the statements of other scholars with which I agree or disagree, and to gather and develop the main arguments that allow me to outline a theoretical model for the study of how persuasive messages can be conveyed through digital games, which I present in the next chapter.

\section{Persuasion through Digital Games: A Theoretical Model}

With the purpose of structuring the existing knowledge that can help to explain how persuasive communication works within digital games, in the sixth chapter of this book I outline a theoretical model to provide a new perspective that helps to make visible how persuasiveness can be structured within digital games. The theoretical model serves to identify specific aspects of advergames' persuasive structure and to analyze them from a new and specific perspective.

To describe the internal persuasive structure of persuasive games, I start by focusing my attention on how other scholars have explained how digital games convey meaning (Bogost, 2007; Raessens, 2009; Salen \& Zimmerman, 2004; Sicart, 2011). A critical analysis of this literature allows me to identify several dimensions involved in the production of meaning within digital games. I subscribe to the idea that players generate the final meaning of a play experience while they play a particular digital game in a given context. Yet, to understand how digital games can be used with persuasive intentions - which is the case with advergames - it is first necessary to study how they can be designed to convey meaning, and how affordances of the game invite specific players' performances. The context of playing can transform the meaning authored into digital games and generate new meanings to a certain extent. Yet, the design of a game gives a particular direction to modes of playing. In this text, I limit my attention to describing how digital games can be designed to convey meaning. Thus, this book will offer a first model of how games are and can be used to convey persuasive messages.

\section{Part III: Advertising through Digital Games}

\section{Persuasive Strategies for Advergames}

The seventh chapter is focused on identifying the factors that determine the conceptualization of advertising strategies for advergames. Identifying these factors also serves to specify which characteristics of advergames 
need to be considered for the conceptualization of advertising strategies for this medium.

Although the theoretical model in this book illuminates how persuasive communication can be implemented within digital games, and therefore is useful for the study and design of persuasive games, it is also important to underline here that each type of persuasive game has a series of characteristics that should be taken into consideration when analyzing or designing its persuasive structure. Accordingly, I claim that advergames have special characteristics that differentiate them from other types of persuasive games and that should be studied separately. The goals of advergames and the attitude of players toward advertising messages distinguish advergames from educational games, for example. Whilst a positive attitude can be expected from players toward the learning goals of educational games, it is important to underline that advertising messages are usually an unwanted form of communication (see Messaris, 1997, p. 5). Therefore, it is conceivable that advergame players would not expect to be persuaded during a game session. It follows that advergames need to overcome players' resistance to the persuasive message (see Klimmt, 2009). Accordingly, in this book, I will identify the factors that should be taken into consideration in order to analyze or design persuasive strategies for advergames.

\section{Case Study: Tem de Tank}

In the eighth chapter, I use the new theoretical model as a tool for the analysis of the advergame Tem de Tank (DDB Amsterdam \& Flavour, 2010). The analysis of the persuasive structure of the game allows me to identify several flaws made in the use of the different persuasive dimensions of the game and to propose design solutions. Consequently, this case study serves to illustrate the usefulness of the theoretical model.

Each of these chapters adds a new layer of inquiry, which ultimately sheds light on a topic scarcely explored hitherto. The theoretical contribution of this book is a fundamental step that can facilitate more exhaustive studies of advergames' effectiveness in the future, an argument that I will revisit in the last chapter of this book, the conclusions. Furthermore, the following chapters try to use game studies, media studies, and persuasive studies approached from a humanities perspective to provide the necessary theoretical knowledge to exploit the full potential of digital games as an advertising medium. Ultimately, this book does not aim to provide a conclusive, allencompassing theoretical model of advergames' persuasiveness but, by focusing on persuasive structures, contributes to a better understanding of the way digital games can convey advertising messages. 


\section{References}

Bogost, I. (2007). Persuasive Games: The Expressive Power of Videogames. Cambridge, MA: MIT Press.

Colbon, J. (2006). Search Marketing Strategies. Oxford: Butterworth-Heinemann. DDB Amsterdam, \& Flavour (2010). Tem de Tank [Digital Game].

DFC Intelligence. (2011). DFC Intelligence Forecasts Global Advertising in Video Games to Reach $\$ 7.2$ billion in 2016. Retrieved 15 December 2012 from http:// www.dfcint.com $/ w p / ? p=315$.

Entertainment Software Association. (2011). 2011. Sales, Demographic and Usage

Data. Essential Facts About the Computer and Video Game Industry.

Epic Games (2017). FortNite [Digital Game]

Zynga (2009). Farmville [Social Media Game]

Forrester (2009). US Interactive Marketing Forecast, 2009 to 2014. Cambridge, MA:

Forrester Research.

Game Oven (2012). Fingle [Digital Game].

Giallourakis, A. (n.d.). Retrieved 14 September 2011, from http://advergames.com/ about.php.

Goodbye, Silverstain, \& Partners (2008). Hotel 626 [Digital Game].

Goodbye Silverstain \& Partners, \& North Kingdom (2010). Battle of Cheetos [Digital Game].

Juul, J. (2010). A Casual Revolution: Reinventing Video Games and their Players. Cambridge, MA: MIT Press.

Karp, S. (2008). The Future of Online Advertising: Entertainment vs. Information. Publishing 2.o. Retrieved 20 September 2011 from http://publishing2.com/2008/04/23/ the-future-of-online-advertising-entertainment-vs-information/.

Klimmt, C. (2009). 'Serious Games and Social Change: Why They (Should) Work'. In: U. Ritterfeld, M. Cody, \& P. Vorderer (eds), Serious Games. Mechanisms and Effects. New York: Routledge.

McCoy, S., Everard, A., Galletta, D., \& Polak, P. (2004). 'A Study of the Effects of Online Advertising: A Focus on Pop-Up and In-Line Ads'. Paper presented at the SIGHCI 2004.

Messaris, P. (1997). Visual Persuasion. London, UK: Sage Publications.

Nielsen, A. (2011). 'Show Me the Stats: Global Advertising Market Size in 2011', Crowd Science. Retrieved 10 November 2011 from http://blog.crowdscience.com/2011/og/ show-me-the-stats-global-advertising-market-size-in-2011/.

Pinto Neto, Z.T. (2007). 'Advergames: Advertisement and Entertainment on the Internet'. Paper presented at the EXPODESIGN. 
Raessens, J. (2009). 'The Gaming Dispositif. An Analysis of Serious Games from a Humanities Perspective'. In: U. Ritterfeld, M. Cody, \& P. Vorderer (eds), Serious Games. Mechanisms and Effects (pp. 486-512). New York, NY: Routledge.

Ryan, D., \& Jones, C. (2011). The Best Digital Marketing Campaigns in the World. London, UK: Kogan Page.

Salen, K., \& Zimmerman, E. (2004). Rules of Play: Game Design Fundamentals. Cambridge, MA: MIT Press.

Sicart, M. (2011). 'Against Procedurality', Game Studies, n(3).

Vedrashko, I. (2006b). 'History of Advergames and In-Game Advertising'. MIT. [Unpublished Thesis]. 
